\title{
A novel set of single-copy nuclear DNA markers for the genetic study of Salicaceae
}

\author{
S.H. Du*, Z.S. Wang* and J.G. Zhang \\ State Key Laboratory of Tree Genetics and Breeding, \\ Key Laboratory of Tree Breeding and Cultivation of the State Forestry \\ Administration, Research Institute of Forestry, \\ Chinese Academy of Forestry, Beijing, China \\ *These authors contributed equally to this study. \\ Corresponding author: J.G. Zhang \\ E-mail: zhangjg@caf.ac.cn
}

Genet. Mol. Res. 13 (3): 4911-4917 (2014)

Received April 9, 2013

Accepted November 31, 2013

Published July 4, 2014

DOI http://dx.doi.org/10.4238/2014.July.4.5

\begin{abstract}
Species of Populus are widely distributed worldwide, playing a significant role in both ecology and economy. However, the lack of single-copy nuclear markers limits knowledge about the phylogeny and population genetics of this genus. In the present study, primer pairs of 15 single-copy nuclear markers were developed through bioinformatic methods based on complete genomic sequences of Populus trichocarpa and Salix arbutifolia. Twenty individuals of Populus davidiana Dode and Salix matsudana Koidz were used to evaluate the basic application of these markers with respect to marker length and diversity indices, respectively. The utility of single-copy nuclear markers is anticipated to facilitate further studies about the phylogeny, population genetics, and phylogeography of this genus, in addition to providing information about the evolutionary dynamics of Salicaceae.
\end{abstract}

Key words: Populus; Salix; Single-copy nuclear markers; Diversity indices 


\section{INTRODUCTION}

The genus Populus is widely distributed from subtropical to boreal forests in the northern hemisphere. This genus contains some of the most commercially exploited trees, and has become a model organism for the study of tree biology (Cronk, 2005; Jansson and Douglas, 2007). Studies about the phylogeny and population genetics of Populus have received particular focus (Smith, 1988; Smith and Sytsma, 1990; Hamzeh and Dayanandan, 2004; Hamzeh et al., 2006; Lee et al., 2011; Levsen et al., 2012). Chloroplast DNA (cpDNA) and nrDNA internal transcribed spacer (ITS) sequences have been used in the phylogeny of Populus (Rajora and Dancik, 1995; Leskinen and Alström-Rapaport, 1999; Shi et al., 2001; Hamzeh and Dayanandan, 2004; Wei et al., 2010). Nevertheless, the phylogenetic relationships among species in this genus remain poorly resolved for several reasons, including the slow rate of sequence divergence, maternal inheritance of cpDNA, and inadequate sequence variation of ITS (Sang, 2002; Small et al., 2004), along with the high level of morphological variation and the extensive interspecific hybridization. Recently, low-copy nuclear genes were used to reconstruct phylogenetic relationships in plants (Peng and Wang, 2008; Yang et al., 2012). However, this procedure often requires much time and effort to obtain these sequences. To resolve the genetic relationship among closely related species of Populus, efficient and highly variable genetic markers with high interspecific diversity are needed. The completion of the P. trichocarpa genome sequence (Tuskan et al., 2006) made it possible to search for orthologous single-copy nuclear sequences, which are expected to serve as useful markers for genetic study of poplar. Here, we reported a novel set of 15 single-copy nuclear markers that were developed based on the genome sequence of P. trichocarpa. Furthermore, to expand the scope of application of these markers, we modified the primers to make them useful for a broader range of Salicaceae species.

\section{MATERIAL AND METHODS}

\section{Biological material}

The biological material was sampled from 1 Populus davidiana population located in Xinjiang, China, and 1 Salix matsudana population (including 1 varietas and 3 forma) located in Beijing, China. In 2012, 20 individuals from each population were sampled. Fresh leaves were collected and stored in plastic bags with silica gel. Four other species (namely $P$. lasiocarpa, P. laurifolia, P. nigra, and P. euphratica), which represented the other 4 sections (Leucoides, Tacamahaca, Aigeiros, and Turanga) of Populus were used to test the utility of these markers in the Populus genus. In addition, Salix arbutifolia and 3 randomly selected willow species (Salix babylonica, S. triandra, and S. raddeana; Table 1) were used to test the broader utility of the modified markers in the Salicaceae family.

\section{Marker procedure}

Populus-specific orthologous single-copy nuclear loci were found using the following bioinformatic methods: first, we searched GENE (http://www.ncbi.nlm.nih.gov/gene) using the single-copy nuclear locus tag provided by Duarte et al. (2010), then linked to the 
KEGG webpage to obtain the amino acid sequence coded by the locus. We then accessed Phytozome (http://phytozome.net/search.php), selected the angiosperm node on the tree in the home page as the search target, and used BLAST as the search tool. After BLAST with the amino acid sequence, we checked the "family view" option with the lowest E-value. On the next gene family page, we clicked the gene page of $P$. trichocarpa, and copied the sequence as the reference sequence. Consequently, we ran the nucleotide BLAST (http://blast. ncbi.nlm.nih.gov/Blast.cgi) using the reference sequence with "other (nr) databases" and "somewhat similar sequence" options, to check whether the locus we chose was a singlecopy in the P. trichocarpa genome.

\section{Table 1. Geographic position of sample site.}

\begin{tabular}{|c|c|c|c|c|c|}
\hline Species & Site name & $\mathrm{N}^{\circ}$ of samples & Latitude & Longitude & Altitude ( $\mathrm{m}$ asl) \\
\hline Populus davidiana & Xinjiang & 20 & $47^{\circ} 23^{\prime} \mathrm{N}$ & $87^{\circ} 50^{\prime} \mathrm{E}$ & 514 \\
\hline P. lasiocarpa & Hubei & 2 & $30^{\circ} 16^{\prime} \mathrm{N}$ & $109^{\circ} 29^{\prime} \mathrm{E}$ & 478 \\
\hline P. laurifolia & Xinjiang & 2 & $47^{\circ} 20^{\prime} \mathrm{N}$ & $87^{\circ} 38^{\prime} \mathrm{E}$ & 529 \\
\hline P. nigra & Germany & 2 & $53^{\circ} 33^{\prime} \mathrm{N}$ & $9^{\circ} 50^{\prime} \mathrm{E}$ & 4 \\
\hline P. euphratica & Xinjiang & 2 & $47^{\circ} 21^{\prime} \mathrm{N}$ & $87^{\circ} 43^{\prime} \mathrm{E}$ & 545 \\
\hline $\begin{array}{l}\text { Salix matsudana } \\
\text { f. pendula } \\
\text { f. tortuosa } \\
\text { f. umbraculifera } \\
\text { var. pseudo-matsudana }\end{array}$ & Beijing & 20 & $39^{\circ} 51^{\prime} \mathrm{N}$ & $116^{\circ} 24^{\prime} \mathrm{E}$ & 49 \\
\hline Salix arbutifolia & Hebei & 2 & $40^{\circ} 40^{\prime} \mathrm{N}$ & $117^{\circ} 14^{\prime} \mathrm{E}$ & 433 \\
\hline S. babylonica & Zhejiang & 2 & $30^{\circ} 16^{\prime} \mathrm{N}$ & $120^{\circ} 09^{\prime} \mathrm{E}$ & 18 \\
\hline S. triandra & Zhejiang & 2 & $30^{\circ} 15^{\prime} \mathrm{N}$ & $120^{\circ} 09^{\prime} \mathrm{E}$ & 20 \\
\hline S. raddeana & Hebei & 2 & $40^{\circ} 38^{\prime} \mathrm{N}$ & $117^{\circ} 14^{\prime} \mathrm{E}$ & 410 \\
\hline
\end{tabular}

\section{DNA isolation, amplification, and sequencing}

Total genomic DNA was extracted from $25 \mathrm{mg}$ leaf tissue from each individual using the methods of Doyle and Doyle (1987). Polymerase chain reactions (PCR) was performed in a total volume of $30 \mu \mathrm{L}$ containing 5 to $50 \mathrm{ng}$ genomic DNA, $2.4 \mu \mathrm{M}$ of each primer, 0.8 $\mu \mathrm{M}$ of each dNTP, $2.0 \mathrm{mM} \mathrm{MgCl}_{2}$, and $0.15 \mathrm{U}$ ex Taq DNA polymerase (TaKaRa, Shiga, Japan). Amplification was carried out in a temperature gradient $96 \mathrm{U}$ thermocycler (Applied Biosystems, Forster City, CA, USA) as follows: $4 \mathrm{~min}$ at $94^{\circ} \mathrm{C}$ followed by 30 cycles of $30 \mathrm{~s}$ at $94^{\circ} \mathrm{C}, 30 \mathrm{~s}$ at $50^{\circ}$ to $60^{\circ} \mathrm{C}$ (depending on the annealing temperature of the specific primers and the length of the amplified regions), $90 \mathrm{~s}$ at $72^{\circ} \mathrm{C}$, and a final extension at $72^{\circ} \mathrm{C}$ for $8 \mathrm{~min}$. Products were examined by electrophoresis on agarose gel and purified using a DNA Purification kit (Amersham Pharmacia Biotech, Piscataway, NJ, USA). The purified DNA was directly sequenced using an ABI 3730 DNA analyzer (Applied Biosystems). The same primers were used for both PCR amplification and sequencing.

Primers were designed using the Primer Premier 5.0 software (Premier Biosoft International, Silicon Valley, CA, USA), based on the reference sequences, which are listed in Table 2. We BLASTed (Altschul et al., 1997) the reference sequences in the draft genome of the $S$. arbutifolia, and assembled the sequence using Illumina next-generation sequencing platform (Du SH, Wang ZS and Zhang JG, unpublished results) to modify the primer pairs for S. matsudana, which are listed in Table 3. 
Table 2. Characteristics of 15 single-copy nuclear markers of Populus davidiana.

\begin{tabular}{|c|c|c|c|c|c|}
\hline Loci & Primer sequences $\left(5^{\prime}-3^{\prime}\right)$ & $\begin{array}{l}\text { Location of } \\
\text { chromosome }\end{array}$ & $\begin{array}{l}\text { PCR product } \\
\text { (bp) }\end{array}$ & $\mathrm{Ta}\left({ }^{\circ} \mathrm{C}\right)$ & GenBank accession No. \\
\hline DSH 1 & $\begin{array}{l}\text { F: ATTGAGGCTTTTGTTCAGCGGTTAT } \\
\text { R: CCTGTACTTGTTTGTCTGGCTTTGT }\end{array}$ & II & $550-589$ & 58 & KC706924-KC706943 \\
\hline DSH 2 & $\begin{array}{l}\text { F: CATCTTTTGCCTTATTGTCTGCT } \\
\text { R: TGCGTTAAATGATCTTTCTGGTA }\end{array}$ & IV & $410-451$ & 56 & КC706944-KC706963 \\
\hline DSH 3 & $\begin{array}{l}\text { F: TCTGCTTTCCACTTCTTGC } \\
\text { R: CATACTCTCCCATTGTCCC }\end{array}$ & VI & $654-680$ & 55 & КC706964-КС706983 \\
\hline DSH 4 & $\begin{array}{l}\text { F: CCACCGCTACTCCTCCG } \\
\text { R: TCCACCCCTCCATCCAC }\end{array}$ & $\mathrm{X}$ & $401-465$ & 58 & КС706984-КС707003 \\
\hline DSH 5 & $\begin{array}{l}\text { F: TGGCAGAATCACCAGACCCTC } \\
\text { R: CCAATTTAGCATCTTCAGCCTCAT }\end{array}$ & XII & $583-622$ & 59 & КC707004-КС707023 \\
\hline DSH 6 & $\begin{array}{l}\text { F: GCCTCCTGATTATTATGC } \\
\text { R: TATTACAAGCCCTTCCAG }\end{array}$ & $X V$ & $456-526$ & 54 & КC707024-KC707043 \\
\hline DSH 7 & $\begin{array}{l}\text { F: TGTCCACAAACGCATCC } \\
\text { R: CAAACTTTACCACCCCA }\end{array}$ & XVI & $512-574$ & 58 & КC707044-КС707063 \\
\hline DSH 8 & $\begin{array}{l}\text { F: GTTTGTTGTTCTGTTGATTGT } \\
\text { R: GGCTTCTCTTCTCTGATATTT }\end{array}$ & XVIII & $531-586$ & 56 & KC707064-KC707083 \\
\hline DSH 10 & $\begin{array}{l}\text { F: TACAAAAGCATTAAAGATCACCACT } \\
\text { R: GGAGCACACTTATCAATAAAACTAC }\end{array}$ & I & $780-842$ & 54 & КC707244-KC707263 \\
\hline DSH 11 & $\begin{array}{l}\text { F: GTGGCAAGACCAGCTGCTAGT } \\
\text { R: ATGGAGGAAGGGTGGACAATG }\end{array}$ & I & $912-1005$ & 55 & КC707264-KC707283 \\
\hline DSH 12 & $\begin{array}{l}\text { F: CACCACATCCCGCTTTCTCTCTTCACTT } \\
\text { R: TAAACCCCAGGAGGCAAAACAGCACCAG }\end{array}$ & II & $496-558$ & 57 & KC707284-KC707303 \\
\hline DSH 14 & $\begin{array}{l}\text { F: TGTTTGATGGACCTGGCTGCT } \\
\text { R: CGGTTTATTGCCTTGTGGAGA }\end{array}$ & III & $845-921$ & 55 & КС707304-КС707323 \\
\hline DSH 15 & $\begin{array}{l}\text { F: CTGAAAGGGAAAATAGTGGACAGTCAA } \\
\text { R: GGATAACAGTAGCATGGAGATATGGAT }\end{array}$ & III & $798-861$ & 56 & КC707304-KC707323 \\
\hline DSH 19 & $\begin{array}{l}\text { F: AAGTCTGGTCAAGGCAGTGGTC } \\
\text { R: TCTGTGCTGTGATGTTTGGGGG }\end{array}$ & XIV & $796-845$ & 54 & КС707344-КС707363 \\
\hline DSH 21 & $\begin{array}{l}\text { F: CATGCTTATGAAGGTGTGGGCTT } \\
\text { R: TGCAAACATCTCACTGGTGACTG }\end{array}$ & XVII & $701-775$ & 53 & КC707364-КС707383 \\
\hline
\end{tabular}

Table 3. Characteristics of 15 single-copy nuclear markers of Salix matsudana.

\begin{tabular}{|c|c|c|c|c|}
\hline Loci & Primer sequences (5'-3') & PCR product (bp) & $\mathrm{Ta}\left({ }^{\circ} \mathrm{C}\right)$ & GenBank accession No. \\
\hline \multirow[t]{2}{*}{ DSL 1} & F: ATTGAGGCTTTTGTTCAGCGGTTAT & $470-484$ & 58 & KC707084-KC707103 \\
\hline & R: CCTGTACTTGTTTGTCTGGCTTTGT & & & \\
\hline \multirow[t]{2}{*}{ DSL 2} & F: CCCTTGGAACCTAGCATGTATTCC & $404-445$ & 56 & КC707104-KC707123 \\
\hline & R: TAGTTCTCATGGCTAAGATATT & & & \\
\hline \multirow[t]{2}{*}{ DSL 3} & F: TCTGCTTTCAACTTCTTGC & $564-635$ & 55 & КC707124-KC707143 \\
\hline & R: CATACTCTCCCATTGTCCC & & & \\
\hline \multirow[t]{2}{*}{ DSL 4} & F: CCACCGCTACTCCTCCG & $451-489$ & 58 & КC707144-KC707163 \\
\hline & R: TCCACATCTCCATCCAC & & & \\
\hline \multirow[t]{2}{*}{ DSL 5} & F: GCCTGGAAAAAACCTAATTTTCAG & $636-658$ & 59 & КC707164-KC707183 \\
\hline & R: CCAGGAGCAGAAGAAAGAACCCG & & & \\
\hline \multirow[t]{2}{*}{ DSL 6} & F: GCCTCCTGATTATTACGC & $573-600$ & 54 & КC707184-KC707203 \\
\hline & R: TATTACAAGCCCTTCCAG & & & \\
\hline \multirow[t]{2}{*}{ DSL 7} & F: GGACAAATACCGTCCACAA & $415-460$ & 58 & KC707204-KC707223 \\
\hline & R: CCTCCAAACTTTACCACCC & & & \\
\hline \multirow[t]{2}{*}{ DSL 8} & F: GTTTGTTGTTCTGTTGATTGT & $556-616$ & 56 & КC707224-КС707243 \\
\hline & R: GGCTTCTCTTCTCTGATATTT & & & \\
\hline \multirow[t]{2}{*}{ DSL 24} & F: TACAAAAGCATTAAAGATCACCACT & $1050-1126$ & 54 & КС707384-КС707403 \\
\hline & R: GGAGCACAGTTATCGATAAAACTAC & & & \\
\hline \multirow[t]{2}{*}{ DSL 25} & F: GTGGCAAGACCAGCTGCTAGT & $671-730$ & 55 & КC707404-КС707423 \\
\hline & R: AAGGAGGGGCAAAGCAAAGCTGTGG & & & \\
\hline \multirow[t]{2}{*}{ DSL 26} & F: TCTCTCTTCACTTGCATATTTATACGCA & $495-535$ & 57 & КC707424-КС707443 \\
\hline & R: TAAACCCCTGGAGGCAAAACAGCACCAG & & & \\
\hline \multirow[t]{2}{*}{ DSL 28} & F: TGTTTGATGGACCTGGCTGCT & 1024-1082 & 55 & КС707444-КС707463 \\
\hline & R: CGGTTTATTGCCTTGTGGAGA & & & \\
\hline \multirow[t]{2}{*}{ DSL 29} & F: CTGAAAGGGAAAATAGTGGACTGTCAA & $779-826$ & 56 & KC707464-KC707483 \\
\hline & R: GGATAACAGTAGCATGGAGATATGGAT & & & \\
\hline \multirow[t]{2}{*}{ DSL 33} & F: AAGTCTGGTCAAGGCAGTGGTC & $521-579$ & 54 & КC707484-КС707503 \\
\hline & R: TCTGCTCTGTGATGTTTGGGTGA & & & \\
\hline \multirow[t]{2}{*}{ DSL 35} & F: CATGCATATGAGGGTGTGGGCTT & 745-786 & 53 & КС707504-КС707523 \\
\hline & R: TGCAAACATCTCATTGCTAACTG & & & \\
\hline
\end{tabular}




\section{Data analysis}

The assembled contigs of each individual were aligned using CLUSTAL X (Thompson et al., 1997) and refined manually in BioEdit (Hall, 1999). The number of haplotypes per locus (A), the number of polymorphic sites $(S)$, the average number of nucleotide differences $(\kappa)$, the nucleotide diversity $(\pi)$, and nucleotide polymorphism $\left(\theta_{\mathrm{w}}\right)$ were analyzed using Dnasp5.10.0 (Librado and Rozas, 2009). The expected heterozygosity $\left(H_{\mathrm{E}}\right)$, the gene diversity $\left(H_{\mathrm{O}}\right)$, and the Tajima D-test were calculated using Arlequin 3.5.1.3 (Excoffier et al., 2005).

\section{RESULTS AND DISCUSSION}

After performing BLAST with the reference sequences of $P$. trichocarpa, all of the searched 30 single-copy nuclear markers were also found to be single copies in the S. arbutifolia genome, of which 8 did not work in amplification and 7 did not work in the sequencing. This result may be attributed to frequent indels in the sequences; hence, these 15 markers were abandoned in the following steps. The other 15 markers performed well in both amplification and sequencing, in which 2 loci (DSH 1 / DSL 1, DSH 8 / DSL 8) were the same, and 13 loci were modified, because of mutations in the primer region. The success rates for the amplification and sequencing of these markers in P. lasiocarpa, P. laurifolia, P. nigra, and P. euphratica, S. arbutifolia, S. babylonica, S. triandra, and S. raddeana were $100 \%$ (data not shown).

After manual refining, the sequences used in analysis were 414-948 bp. The number of haplotypes per locus ranged from 4 to 17 , with a mean of 11. An average of 11 polymorphic sites was obtained. The average number of nucleotide differences ranged from 1.23 to 5.78, with an average of 3.72. The genetic polymorphism parameters of $\pi, \theta_{\mathrm{w}}, H_{\mathrm{E}}$, and $H_{\mathrm{O}}$ were, on average, $0.00603,0.00410,0.338$, and 0.792 , respectively. This result indicated that $P$. $d a$ vidiana had high genetic diversity. The results of the Tajima D-test showed that all loci were consistent with the neutral theory at $\mathrm{P}>0.05$ (Table 4).

\begin{tabular}{|c|c|c|c|c|c|c|c|c|c|c|}
\hline Locus & $\mathrm{N}$ & Length (bp) & A & $\mathrm{S}$ & $\pi$ & $\theta_{\text {H }}$ & $\kappa$ & $H_{\mathrm{E}}$ & $H_{\mathrm{o}}$ & Tajima D \\
\hline$\overline{\mathrm{DSH}} 1$ & 20 & 537 & 10 & 17 & 0.0108 & 0.00747 & 5.78 & 0.309 & 0.774 & 1.45 \\
\hline DSH 2 & 20 & 414 & 17 & 15 & 0.0134 & 0.00854 & 5.55 & 0.350 & 0.913 & 1.83 \\
\hline DSH 3 & 20 & 643 & 9 & 11 & 0.00417 & 0.00404 & 2.67 & 0.219 & 0.767 & 0.0951 \\
\hline DSH 4 & 20 & 428 & 9 & 6 & 0.00556 & 0.00330 & 2.37 & 0.371 & 0.745 & 1.60 \\
\hline DSH 5 & 20 & 559 & 10 & 10 & 0.00636 & 0.00422 & 3.54 & 0.326 & 0.796 & 1.51 \\
\hline DSH 6 & 20 & 474 & 8 & 6 & 0.00451 & 0.00297 & 2.14 & 0.358 & 0.760 & 1.39 \\
\hline DSH 7 & 20 & 529 & 4 & 3 & 0.00232 & 0.00133 & 1.23 & 0.409 & 0.539 & 1.61 \\
\hline DSH 8 & 20 & 566 & 9 & 8 & 0.00536 & 0.00332 & 3.03 & 0.379 & 0.677 & 1.75 \\
\hline DSH 10 & 20 & 804 & 17 & 16 & 0.00525 & 0.00468 & 4.22 & 0.264 & 0.931 & 0.394 \\
\hline DSH 11 & 20 & 948 & 8 & 9 & 0.00258 & 0.00223 & 2.45 & 0.272 & 0.728 & 0.460 \\
\hline DSH 12 & 20 & 528 & 10 & 10 & 0.00709 & 0.00445 & 3.75 & 0.375 & 0.863 & 1.77 \\
\hline DSH 14 & 20 & 881 & 17 & 14 & 0.00601 & 0.00374 & 5.30 & 0.374 & 0.874 & 1.92 \\
\hline DSH 15 & 20 & 834 & 14 & 16 & 0.00641 & 0.00449 & 5.37 & 0.331 & 0.873 & 1.38 \\
\hline DSH 19 & 20 & 826 & 11 & 15 & 0.00670 & 0.00421 & 5.54 & 0.369 & 0.751 & 1.82 \\
\hline DSH 21 & 20 & 739 & 11 & 8 & 0.00385 & 0.00255 & 2.84 & 0.365 & 0.883 & 1.45 \\
\hline Mean & 20 & 647 & 11 & 11 & 0.00603 & 0.00410 & 3.72 & 0.338 & 0.792 & 1.36 \\
\hline
\end{tabular}

The length of 15 sequenced loci in S. matsudana was 417-1096 bp, with an average of $634 \mathrm{bp}$. The average number of haplotype and polymorphic sites were 10 and 11, respectively, 
which were similar to those of poplar. The average number of nucleotide differences ranged from 0.322 to 12.0 , with an average of 4.34 , which was higher compared to poplar. The values of $\pi, \theta_{\mathrm{w}}, H_{\mathrm{E}}$, and $H_{\mathrm{O}}$ also showed the presence of high genetic diversity in S. matsudana. Moreover, the D values of 9 loci (DSL 1, DSL 3, DSL 5, DSL 7, DSL 24, DSL 28, DSL 29, DSL 33, and DSL 35) significantly deviated from that expected by the neutral model $(\mathrm{P}<0.05)$ (Table 5). Given that 1 varietas and 3 forma were included in the analysis, it was expected that alleles existed in high frequencies in different loci that had been derived from divergent taxonomic units. Alternatively, balancing selection might have been present in these loci. Therefore, further research should be conducted about these loci.

\begin{tabular}{|c|c|c|c|c|c|c|c|c|c|c|}
\hline Locus & $\mathrm{N}$ & Length (bp) & A & $\mathrm{S}$ & $\pi$ & $\theta_{\mathrm{w}}$ & $\kappa$ & $H_{\mathrm{E}}$ & $H_{\mathrm{O}}$ & Tajima D \\
\hline$\overline{\text { DSL } 1}$ & 20 & 471 & 11 & 19 & 0.0193 & 0.00948 & 9.09 & 0.479 & 0.878 & 3.40 \\
\hline DSL 2 & 20 & 417 & 10 & 9 & 0.00417 & 0.00510 & 1.73 & 0.192 & 0.833 & -0.534 \\
\hline DSL 3 & 20 & 584 & 10 & 24 & 0.0206 & 0.00966 & 12.0 & 0.500 & 0.897 & 3.81 \\
\hline DSL 4 & 20 & 445 & 9 & 8 & 0.00383 & 0.00423 & 1.70 & 0.213 & 0.603 & -0.266 \\
\hline DSL 5 & 20 & 605 & 7 & 9 & 0.00685 & 0.00350 & 4.15 & 0.461 & 0.833 & 2.80 \\
\hline DSL 6 & 20 & 564 & 4 & 3 & 0.00213 & 0.00125 & 1.20 & 0.401 & 0.650 & 1.54 \\
\hline DSL 7 & 20 & 427 & 14 & 12 & 0.0125 & 0.00661 & 5.35 & 0.446 & 0.910 & 2.76 \\
\hline DSL 8 & 20 & 532 & 3 & 2 & 0.000600 & 0.000880 & 0.322 & 0.161 & 0.309 & -0.596 \\
\hline DSL 24 & 20 & 1096 & 18 & 8 & 0.00310 & 0.00172 & 3.38 & 0.425 & 0.901 & 2.29 \\
\hline DSL 25 & 20 & 709 & 10 & 8 & 0.00403 & 0.00265 & 2.86 & 0.357 & 0.863 & 1.48 \\
\hline DSL 26 & 20 & 508 & 6 & 9 & 0.00105 & 0.00417 & 0.938 & 0.104 & 0.395 & -1.63 \\
\hline DSL 28 & 20 & 1065 & 11 & 7 & 0.00279 & 0.00155 & 2.97 & 0.424 & 0.894 & 2.22 \\
\hline DSL 29 & 20 & 806 & 11 & 20 & 0.0122 & 0.00583 & 9.79 & 0.490 & 0.897 & 3.58 \\
\hline DSL 33 & 20 & 547 & 12 & 19 & 0.0163 & 0.00817 & 8.92 & 0.469 & 0.908 & 3.28 \\
\hline DSL 35 & 20 & 743 & 7 & 11 & 0.00099 & 0.00348 & 0.732 & 0.0666 & 0.396 & -2.18 \\
\hline Mean & 20 & 634 & 10 & 11 & 0.00736 & 0.00455 & 4.34 & 0.346 & 0.744 & 1.46 \\
\hline
\end{tabular}

\section{CONCLUSIONS}

We presented a novel set of 15 single-copy nuclear markers that were specifically developed for Salicaceae, and utility in $P$. davidiana and $S$. matsudana. The combined phylogenetic inference of Populus when using these markers as outgroups, along with the markers of other willow species, is currently in progress, and the preliminary results are promising. Although previous studies have focused on the phylogeny of Populus, there has been extensive debate on the relationships among species and the placement of some species (which might have originated through hybridization). This set of efficient and highly resolved molecular markers is anticipated to be of particular use in phylogenic and population genetics, as well as for elucidating the evolutionary dynamics of Populus species and the Salicaceae family.

\section{ACKNOWLEDGMENTS}

We thank Dr. Duan Aiguo and Dr. Zhang Xiongqing for the sampling of biological material. We also thank Dr. Zeng Yanfei for assistance with the data analysis and providing suggestions on a preliminary vision of this paper. Financial support for this research was provided by the Special Research Program for Public-Welfare Forestry of China (\#201004035), the Key Project of Research Institute of Forestry, Chinese Academy of Forestry, China (\#ZD200911), 
the Specialized Research Fund for Young Scholars of the Research Institute of Forestry, Chinese Academy of Forestry, China (\#RIF 2012-06) and the Collaborative Innovation Plan of Jiangsu Higher Education.

\section{REFERENCES}

Altschul SF, Madden TL, Schäffer AA, Zhang J, et al. (1997). Gapped BLAST and PSI-BLAST: a new generation of protein database search programs. Nucleic Acids Res. 25: 3389-3402.

Cronk QC (2005). Plant eco-devo: the potential of poplar as a model organism. New Phytol. 166: 39-48.

Doyle JJ and Doyle JL (1987). A rapid DNA isolation procedure for small quantities of fresh leaf tissue. Phytochem. Bull. 19: 11-15.

Duarte JM, Wall PK, Edger PP, Landherr LL, et al. (2010). Identification of shared single copy nuclear genes in Arabidopsis, Populus, Vitis and Oryza and their phylogenetic utility across various taxonomic levels. BMC Evol. Biol. 10: 61.

Excoffier L, Laval G and Schneider S (2005). Arlequin (version 3.0): an integrated software package for population genetics data analysis. Evol. Bioinform. Online 1: 47-50.

Hall TA (1999). BioEdit: a user-friendly biological sequence alignment editor and analysis program for Windows 95/98/ NT. Nucleic Acids Symposium Series 41: 95-98.

Hamzeh M and Dayanandan S (2004). Phylogeny of Populus (Salicaceae) based on nucleotide sequences of chloroplast TRNT-TRNF region and nuclear rDNA. Am. J. Bot. 91: 1398-1408.

Hamzeh M, Périnet P and Dayanandan S (2006). Genetic Relationships among species of Populus (Salicaceae) based on nuclear genomic data 1. J. Torrey Bot. Soc. 133: 519-527.

Jansson S and Douglas CJ (2007). Populus: a model system for plant biology. Annu. Rev. Plant Biol. 58: 435-458.

Lee KM, Kim YY and Hyun JO (2011). Genetic variation in populations of Populus davidiana Dode based on microsatellite marker analysis. Genes Genomics 33: 163-171.

Leskinen E and Alström-Rapaport C (1999). Molecular phylogeny of Salicaceae and closely related Flacourtiaceae: Evidence from 5.8s, ITS1 and ITS2 of the rDNA. Plant Systemat. Evol. 215: 209-227.

Levsen ND, Tiffin P and Olson MS (2012). Pleistocene speciation in the genus Populus (Salicaceae). Syst. Biol. 61: 401412.

Librado P and Rozas J (2009). DnaSP v5: a software for comprehensive analysis of DNA polymorphism data. Bioinformatics 25: 1451-1452.

Peng D and Wang XQ (2008). Reticulate evolution in Thuja inferred from multiple gene sequences: implications for the study of biogeographical disjunction between eastern Asia and North America. Mol. Phylogenet. Evol. 47: 1190-1202.

Rajora OP and Dancik BP (1995). Chloroplast DNA variation in Populus. I. Intraspecific restriction fragment diversity within Populus deltoides, P. nigra and P. maximowiczii. Theor. Appl. Genet. 90: 317-323.

Sang T (2002). Utility of low-copy nuclear gene sequences in plant phylogenetics. Crit. Rev. Biochem. Mol. Biol. 37 : 121-147.

Shi QL, Zhuge Q, Huang MR and Wang MX (2001). Phylogenetic relationship of Populus sections by ITS sequence analysis. Acta Bot. Sin. 43: 323-325.

Small RL, Cronn RC and Wendel JF (2004). LAS Johnson Review No. 2. Use of nuclear genes for phylogeny reconstruction in plants. Aust. Syst. Bot. 17: 145-170.

Smith RL (1988). Phylogenetics of Populus L. (Salicaceae) Based on Restriction Site Fragment Analysis of cpDNA. Master's thesis, University of Wisconsin-Madison, Wisconsin.

Smith RL and Sytsma KJ (1990). Evolution of Populus nigra (sect. Aigeiros): introgressive hybridization and the chloroplast contribution of Populus alba (sect. Populus). Am. J. bot. 77: 1176-1187.

Thompson JD, Gibson TJ, Plewniak F, Jeanmougin F, et al. (1997). The CLUSTAL_X windows interface: flexible strategies for multiple sequence alignment aided by quality analysis tools. Nucleic Acids Res. 25: 4876-4882.

Tuskan GA, Difazio S, Jansson S, Bohlmann J, et al. (2006). The genome of black cottonwood, Populus trichocarpa (Torr. \& Gray). Science 313: 1596-1604.

Wei ZZ, Guo LQ, Zhang JF, Li BI, et al. (2010). Phylogenetic relationship of Populus by trnL-F sequence analysis. J. Beijing Forest Univ. 32: 27-33.

Yang ZY, Ran JH and Wang XQ (2012). Three genome-based phylogeny of Cupressaceae s.1.: further evidence for the evolution of gymnosperms and Southern Hemisphere biogeography. Mol. Phylogenet. Evol. 64: 452-470. 